\title{
Inwards, together: an inner-resourcing U-turn
}

Deena Shaffer

X/Ryerson University, Canada

Diana Brecher

X/Ryerson University, Canada

Keywords: metacognition; somatic; embodiment; mindfulness; pendulation; Covid-19.

\section{The challenge}

Our challenge was to offer students something screen-free to support their academic and personal wellbeing and to utilise their self-reliance. We were driven to help in some way - via curriculum, resources, and strategies - during the prolonged Covid-19 pandemic and its associated isolation, loneliness, digital dependence, and fragmentation. We felt compelled to explore how thriving at the heart of our professional programmes might still be possible, even if only in micro-moments, given the Covid-19 context. We wondered what we could suggest that students could turn to independent of time zones, literal bandwidth, and space constraints. This led us to incorporate inner-resourcing strategies into our nationally recognised programme, Thriving in Action (TiA).

TiA began just over four years ago at X/Ryerson University in Toronto, Canada, where it has so far supported more than 1,000 students and spawned a community of practice involving colleagues in 35 Canadian post-secondary institutions. In its original form, TiA welcomed students from all years and programmes who self-identified as academically or personally struggling into a semester-long cohort to learn Positive Psychology essentials, like selfcompassion and gratitude, intertwined with integrative learning strategies. While many core aspects remain, what has changed is an enhanced commitment to offer students ever-ready, somatic approaches to well-regulate, refocus, and re-embody. 


\section{The response}

Thriving in Action became Thriving at Home, offered synchronously via Zoom to students keen to learn how to cope, and to learn well. Metacognition remained a key underpinning: that 'awareness above the subject matter' (Chick, 2013, para. 3) and 'supervisory thinking' (Handel, 2020, para. 3), help us work through 'the Muddiest Point' (Tanner, 2012, p.116) and become more consciously aware of how learning is happening (McGuire, 2015). But metacognitive strategies were not enough, and maybe not altogether possible, in the face of Covid-19's collective trauma.

TiA had offered tips like stacking to form new habits (Wood, 2019), enacting gratitude to support mood, and immersion in nature to hone concentration (Kaplan, 1995) for more effective note-taking. Thriving at Home provides these same proven strategies alongside grounding body- and breath- based techniques. The pandemic-prompted shift resembles a Uturn, a move from TiA's more external practices to Thriving at Home's inner ones. These new strategies tap into students' own capacities, requiring nothing beyond a students' own presence here and now - no data, no office hours, no appointment.

In this U-turn towards somatic and sensory strategies to soften, soothe, and ease, we explored what counts as a learning strategy. We centred embodiment, 'critical for well-being' (Berila, 2016, p.33), recognising that 'we learn through our bodies and spirits as much as through our minds' (Cajete, 1994, p.31). For example, we taught pendulation (Levine and Frederick, 1997) to notice, feel, and remedy when we are stuck or overwhelmed and to sway, like a pendulum, back into a state of restoration.

We also outlined the impacts of the vagus nerve, drawing on the insights of Polyvagal Theory (Porges, 2011), reminding students of the dynamic dance we are each in, every day, between the dorsal vagal state of shut down, the sympathetic state of mobilised and primed to take action, and the ventral vagal state of feeling steady and safe to engage in relationship and integration. We spoke to the ebb and flow of bodies' physiological resilience, namely what readiness to learn feels like, aiming for a balance between being 'not too revved up. Not too shut down, regulated, relational, rational, and reflective . . . recover[ing] capacities of learning 
and growth' (Graham, n.d., p.2).

Alongside pendulation and polyvagal pedagogy, sleep became another foremost learning strategy, not pushed to the outer edges of the day if, only, and after finishing schoolwork, but as a primary insistence. Sleep, after all, enables our ability to absorb experiences and consolidate them as memories, facilitates the transition of memories from short- to long-term storage, and leads to a threefold upping of creative problem-solving (Walker, 2019).

Breath-work in the form of beneficial pacing of our inhales and exhales (Bullock, 2019) became another key strategy in students' expanding toolkit of holistic learning strategies; we practised a steady, even rhythm of breathing in for a count of four and then out, and as a grounding salve to rising panic, we practised holding breaths to re-nourish mental focus and calm agitation. We also practised sense-based anxiety reduction techniques, like noticing and naming five nearby items to see, four to touch, three sounds, two smells, and one taste, all to pierce through rumination and re-inhabit the body. We practised intentional, constructive rest postures, like placing legs up on a wall or on a chair, to stimulate pendulation away from being always-on, activated, and adrenaline-fuelled. We practised tracing our fingers, as well as clenching and unclenching our fists, in sync with the breath. We practised experimenting with self-calming techniques that tap into the mammalian caregiving system, like cupping palms on cheeks or hands over heart, and we practised accessible slow stretch routines to better hear our inner yearning for rest, relaxation, hydration, and laughter.

From heart rate variability interventions to pranayama offerings, we enfolded these myriad, somatic, micro-resilience (John, 2017) strategies and techniques as learning strategies. Each helped Thriving at Home students to feel bodily feedback - fatigue, dehydration, panic, avoidance - and to respond skilfully.

\section{Recommendations}

Thriving at Home students articulated that they had previously viewed movement, sleep, and even breath-awareness as luxuries, secondary to schoolwork at best. Now, their learning strategy repertoires overflowed with nourishing, embodied, always-available approaches that 
directly support metacognition, efficiency, productivity, reflection, and growth mind-set, and that place wellbeing at the centre of learning.

Having students prioritise these strategies as necessary, rather than nice-to-have, amongst their list of weighty to-dos has been tricky. We will continue to intersperse these somatic approaches from herein. Based on our learning, we recommend that learning developers, and educators more broadly, rethink what gets silo-ed out or excluded from education development work, and aim to broaden what has traditionally been thought of as a metacognitive or learning strategy; perhaps broaden your suggestions, searches, and scholarly work to incorporate elemental, ever-ready, holistic dimensions. Consider making your own U-turn and tenderly attend to the wisdom of your own breath and the feedback of your own body and go from there.

\section{References}

Berila, B. (2016) Integrating mindfulness into anti-oppression pedagogy: social justice in higher education. New York: Routledge.

Bullock, G. B. (2019) 'What focusing on the breath does to your brain', Greater Good Science Center, 31 October. Berkeley: Greater Good in Action. Available at: https://greatergood.berkeley.edu/article/item/what_focusing_on_the_breath_does_to_yo ur_brain\#: :text=A\%20recent\%20study\%20in\%20the,pay\%20attention\%20to\%20our\% 20breath.\&text=Prior\%20research\%20shows\%20that\%20paced,and\%20regulate\%20t he\%20nervous\%20system (Accessed: 25 October 2021).

Cajete, G. (1994) Look to the mountain: an ecology of indigenous education. Durango: Kivaki Press.

Chick, N. (2013) Metacognition. Vanderbilt University Center for Teaching. Available at: https://cft.vanderbilt.edu/guides-sub-pages/metacognition/ (Accessed: 9 June 2021).

Graham, L. (n.d.) Practical treatment strategies to foster post-traumatic growth [Training Journal of Learning Development in Higher Education, Issue 22: Compendium October 2021 
transcript]. National Institute for Clinical Application of Behavioral Medicine. Available at: https://s3.amazonaws.com/nicabm-stealthseminar/PostTraumaticGrowthShortCourse+/Transcript/Video7.pdf (Accessed: 28 October 2021).

Handel, D. (2020) 'The power of metacognition in everyday life', The Learning Scientists, 2 April. Available at: https://www.learningscientists.org/blog/2020/4/2-1 (Accessed: 25 October 2021).

John, B. S. (2017) Micro-resilience: minor shifts for major boosts in focus, drive, and energy. Nashville: Center Street.

Kaplan, S. (1995) 'The restorative benefits of nature: toward an integrative framework', Journal of Environmental Psychology, 15(3), pp.169-182. https://doi.org/10.1016/02724944(95)90001-2.

Levine, P. A. and Frederick, A. (1997) Waking the tiger. Healing trauma: the innate capacity to transform overwhelming experiences. Berkeley: North Atlantic Books.

McGuire, S. Y. (2015) Teach students how to learn: Strategies you can incorporate into any course to improve student metacognition, study skills, and motivation. Sterling: Stylus Publishing, LLC.

Porges, S. W. (2011) The polyvagal theory: Neurophysiological foundations of emotions, attachment, communication, and self-regulation. New York: W.W. Norton \& Company.

Tanner, K. D. (2012) 'Promoting student metacognition', CBE-Life Sciences Education, 11, pp.113-120. https://doi.org/10.1187/cbe.12-03-0033.

Walker, M. (2019) Sleep is your superpower [Video]. TED Conferences. Available at: https://www.ted.com/talks/matt_walker_sleep_is_your_superpower?language=en (Accessed: 25 October 2021). 
Wood, W. (2019) Good habits, bad habits: the science of making positive changes that stick. New York: Farrar, Straus and Giroux.

\section{Author details}

Deena Kara Shaffer is co-author of the Thriving in Action academic flourishing intervention, Adjunct Sociology Faculty, and Psychology Lecturer at X/Ryerson University. Deena is the President of the Learning Specialists Association of Canada. A former learning strategist for students with disabilities, and a skilled certified high school teacher, Deena offers an equityguided, research-driven, and health-promoting approach. Deena holds a doctorate in naturebased pedagogy; is a trained yoga, restorative yoga, and mindfulness meditation teacher; is a published poet (The Grey Tote, Véhicule Press, 2013); and is also the owner of Awakened Learning integrative coaching and consulting.

Diana Brecher is a Clinical Psychologist at X/Ryerson University, where she has been a therapist, supervisor, and director for more than 30 years. Diana teaches graduate-level psychology courses at OISE/UT and X/RU. Diana's long-standing interest and certification in Positive Psychology culminated in the development of ThriveRU, a comprehensive, campuswide resilience-based training program for students, faculty and staff, and the co-development of Thriving in Action. Diana has offered resilience training to patients and staff at Sunnybrook Hospital, North York General Hospital, Toronto's University Health Network, and Espanola Regional Hospital and Health Centre. 